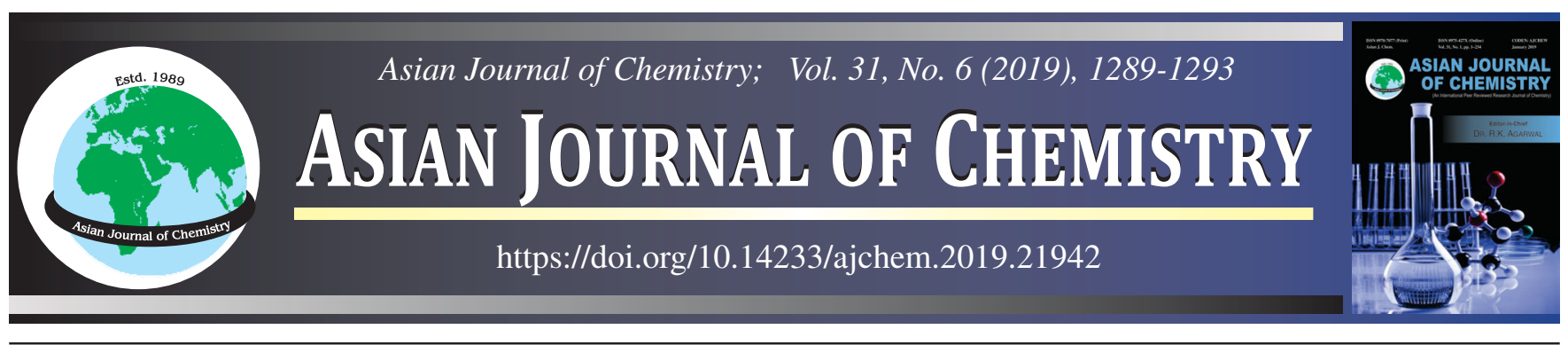

\title{
Synthesis, Spectral Characterization and Antibacterial Activity of Copper(II) Complexes of Functionalized Hydrazones
}

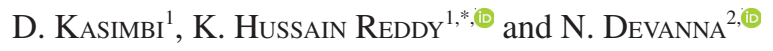

${ }^{1}$ Department of Chemistry, Sri Krishnadevaraya University, Ananthapuramu-515003, India

${ }^{2}$ Department of Chemistry, Jawaharlal Nehru Technological University, Ananthapuramu-515002, India

*Corresponding author: E-mail: khussainreddy@yahoo.co.in

Received: 18 January 2019;

Accepted: 12 February 2019;

Published online: 29 April 2019;

AJC-19370

Copper(II) complexes having the formula $\mathrm{CuL}_{2}$ \{where, $\mathrm{L}=2$-acetylthiophene acetoylhydrazone (ATAH), 2-acetylthiophene benzoylhydrazone $(\mathrm{ATBH})\}$ have been investigated on the basis of elemental analysis, molar conductivity measurements, magnetic susceptibility, UV-visible, IR and ESR spectral data. Non-electrolytic nature of the complexes are revealed by molar conductance data. IR spectral data suggested that hydrazones act as tridentate ligands. The spin Hamiltonian, orbital reduction and bonding parameters of complexes are calculated using ESR spectra of complexes. The compounds are screened for their antibacterial activities against Pseudomonas aureoginos and Bacillus cereus. Acetoylhydrazones show more antibacterial activity than the corresponding benzoyl hydrazones. Some of the $\mathrm{Cu}$ (II) complexes show more activity than hydrazone ligands.

Keywords: Copper(II) complexes, Trifunctional donor ligands, Octahedral geometry, Antibacterial activity.
\end{abstract}

ᄂ _ - - - - - - - - - - - - - - -

\section{INTRODUCTION}

Copper proteins have attracted considerable attention owing to their biological functions such as electron transport, oxygen transport, copper storage and many oxidase activities [1]. Copper is biostatic metal and its surface have natural properties which can destroy a wide range of microorganisms [2].

Current interest in copper complexes springs from their immense use as pharmacological agents. Tridentate Schiff base ligands form stable complexes by bonding through potential donor atoms. However, copper complexes with tridentate ligands with thiophene moiety and having assorted donor $(\mathrm{N}, \mathrm{O}, \mathrm{S})$ atoms are limited [3].

Metal complexes of hydrazones have wide applications in biological processes [4-15]. A good number of transition metal complexes with hydrazones have been reported [16]. Our survey of literature revealed that only few reports are available on the antibacterial activity of such complexes with hydrazones. $\mathrm{Cu}$ (II) and $\mathrm{Zn}$ (II) complexes with 2-benzoylpyridinemethylhydrazone are reported by Beraldo et al. [17]. Koo et al. [18] reported $\mathrm{Mn}(\mathrm{II}), \mathrm{Co}(\mathrm{II}), \mathrm{Ni}(\mathrm{II}), \mathrm{Cu}(\mathrm{II})$ and $\mathrm{Zn}(\mathrm{II})$ complexes of 2-acetylpyridine benzoylhydrazone. Recently, we have studied
[19-22] lanthanide complexes of 2-benzoylpyridine benzoylhydrazone, 2-acetylpyridine acetoylhydrazone, 2-benzoylpyridine acetoylhydrazone and 2-formylpyridine benzoylhydrazone. Recently, DNA binding and cleavage activities on $\mathrm{Cu}$ (II) complexes with tetradentate ligands is also reported in the literature [23]. However, there is no report on antibacterial property of copper derivatives of hydrazones derived from 2-acetylthiophene. These ligands contain assorted donor (N, $\mathrm{O}$ and $\mathrm{S}$ ) atoms and expected to form complexes with copper and to show interesting properties and activities.

Based on the lacuna identified and to renew our research interests [24-28], herein we reported the current findings on copper(II) complexes of 2-acetylthiophene acetoylhydrazone (ATAH) and 2-acetylthiophene benzoylhydrazone (ATBH).

\section{EXPERIMENTAL}

The organic precursors (2-acetylthiophene, acetic hydrazide and benzhydrazide) were purchased from Sigma-Aldrich Chemicals Pvt. Ltd. India. The copper salt $\left(\mathrm{CuCl}_{2} \cdot 2 \mathrm{H}_{2} \mathrm{O}\right)$ was purchased from Merck Company. Only distilled solvents were used in the preparation of hydrazones and their metal derivatives.

This is an open access journal, and articles are distributed under the terms of the Creative Commons Attribution-NonCommercial-ShareAlike 4.0 (CC BY-NC-SA 4.0) International License which allows readers to freely read, download, copy, distribute, print, search, or link to the full texts of its articles and to use them for any other lawful non-commercial purpose as long as the original source is duly acknowledged. 
Preparation of 2-acetylthiophene acetoylhydrazone (ATAH): Acetic hydrazide ( $3.0 \mathrm{~g}, 0.03 \mathrm{~mol})$ dissolved in 20 $\mathrm{mL}$ methanol was added to a hot methanolic solution $(20 \mathrm{~mL})$ of 2-acetylthiophene $(5.03 \mathrm{~mL}, 0.03 \mathrm{~mol})$ in a $100 \mathrm{~mL}$ round bottom flask. Few drops of glacial $\mathrm{CH}_{3} \mathrm{COOH}$ was added to the reaction mixture. The contents were refluxed over water bath for $2 \mathrm{~h}$ and cooled to room temperature. By filtration, the compound was collected. It was washed 3-4 times with $2 \mathrm{~mL}$ portions of hot water and finally dried in vacuo. The product was recrystallized from methanol (Scheme-I). Yield: $80 \%$ m.p.: $176-178^{\circ} \mathrm{C}$.

Preparation of 2-acetylthiophene benzoylhydrazone (ATBH): Benzhydrazide (3 g, $0.02 \mathrm{~mol})$ dissolved in $20 \mathrm{~mL}$ methanol was added to a hot methanolic solution $(20 \mathrm{~mL})$ of 2-acetylthiophene $(2.7 \mathrm{~mL}, 0.03 \mathrm{~mol})$ in a $100 \mathrm{~mL}$ round bottom flask. Few drops glacial $\mathrm{CH}_{3} \mathrm{COOH}$ was added to the reaction mixture. The contents were refluxed over water bath for $2 \mathrm{~h}$ and cooled to room temperature. By filtration, the compound formed was collected and washed 3-4 times with $2 \mathrm{~mL}$ portions of hot water and finally dried in vacuo. It was recrystallized from methanol (Scheme-II). Yield: $85 \%$; m.p. 198-200 ${ }^{\circ} \mathrm{C}$.

\section{Synthesis of copper complexes}

Preparation of $\mathrm{Cu}(\mathrm{ATAH})_{2}$ : The complex was prepared by mixing hot methanolic solution $(20 \mathrm{~mL})$ of 2-acetylthiophene acetoylhydrozone (ATAH) $(1 \mathrm{~g}, 0.55 \mathrm{mmol})$ and $\mathrm{CuCl}_{2} \cdot 2 \mathrm{H}_{2} \mathrm{O}$ $(0.63 \mathrm{~g}, 0.55 \mathrm{mmol})$ dissolved in methanol $(20 \mathrm{~mL})$ in $1: 1$ ratio in a clean $100 \mathrm{~mL}$ round bottom flask and the contents were refluxed on water bath for $3 \mathrm{~h}$. The resulting solution was allowed to stand at room temperature and after slow evaporation, light green coloured complex which separated out was collected by filtration, washed with methanol followed by hexane and dried in vacuo. Yield, $72 \%$; decomposition point: $>290^{\circ} \mathrm{C}$.

Preparation of $\mathrm{Cu}(\mathrm{ATBH})_{2}$ : It was prepared by mixing hot ethanolic solution $(20 \mathrm{~mL})$ of 2-acetylthiophene benzoylhydrozone $(\mathrm{ATBH})(1 \mathrm{~g}, 0.410 \mathrm{mmol})$ and $\mathrm{CuCl}_{2} \cdot 2 \mathrm{H}_{2} \mathrm{O}(0.53$ $\mathrm{g}, 0.410 \mathrm{mmol})$ dissolved in ethanol (sprit) $(20 \mathrm{~mL})$ in $1: 1$ ratio in a clean $100 \mathrm{~mL}$ round bottom flask and the contents were refluxed on water bath for $3 \mathrm{~h}$. The resulting solution was allowed to stand at room temperature and after slow evaporation, dark green coloured complex which was separated out by filtration, washed with methanol followed by hexane and dried in vacuo. Yield: $70 \%$; decomposition point: above $290{ }^{\circ} \mathrm{C}$.

Preparation of sample solution for antimicrobial activity: With different concentrations of 200,300 and $500 \mu \mathrm{g}$ of each compound was prepared in DMF that had no influence on the microbial growth.

Test microorganisms and growth media: Bacillus cereus (MTCC 1305) and Pseudomonas aureoginosa (MTCC 2453) were targeted in the present study and procured from Department of Microbiology, Osmania University College, Hyderabad, India. The bacteria were grown on Mueller-Hinton agar plates at $37^{\circ} \mathrm{C}$. The bacterial stock cultures were incubated for $24 \mathrm{~h}$ at $37^{\circ} \mathrm{C}$ on nutrient agar. Antibacterial activities of ligands and complexes were determined by zone inhibition method. Standard procedures were used in the preparation of paper discs.

Antibacterial activity: The agar medium was sterilized at $121^{\circ} \mathrm{C}$ for $30 \mathrm{~min}$. By pouring about $10 \mathrm{~mL}$ of the medium into petri-dishes (diameter $=10 \mathrm{~cm}$ ) under aseptic condition the agar plates were prepared. The plates left undisturbed for $2 \mathrm{~h}$ to solidify the medium. About $1 \mathrm{~mL}$ aliquot of inoculums (containing suspension) of bacteria was poured on to the plates

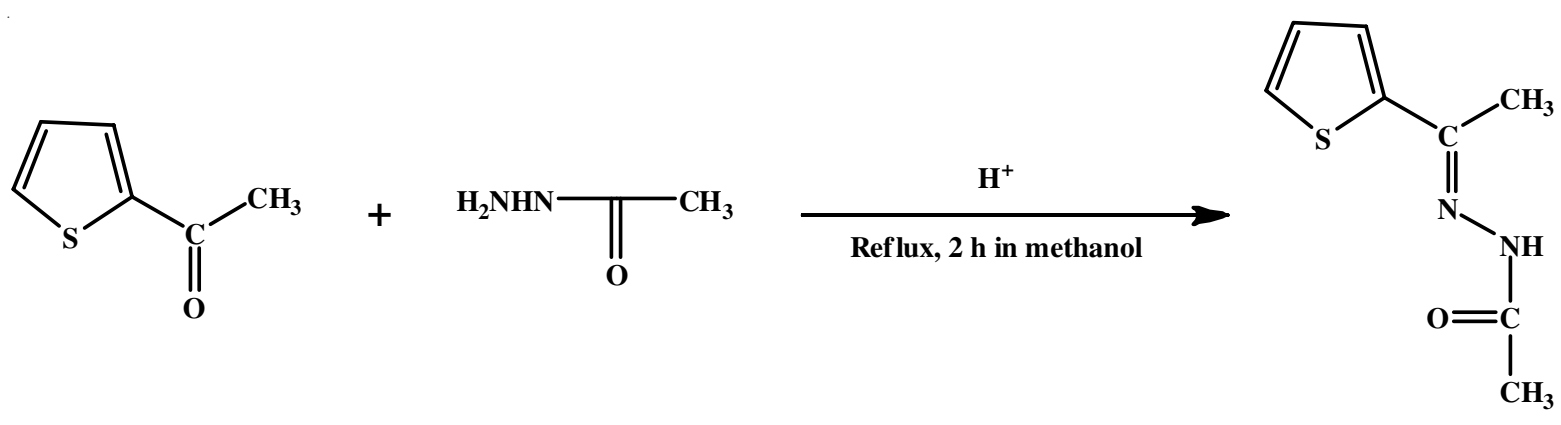

Scheme-I: Synthesis of 2-acetylthiophene acetoylhydrozone (ATAH)<smiles>CC(=O)c1cccs1</smiles><smiles>NNC(=O)c1ccccc1</smiles>

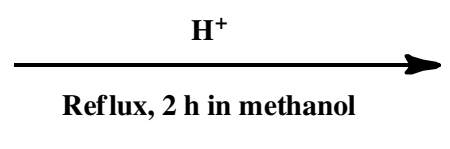<smiles>C/C(=N\NC(=O)c1ccccc1)c1cccs1</smiles>

Scheme-II: Synthesis of 2-acetylthiophene benzoyl hydrozone (ATBH) 
TABLE-1

ANALYTICAL DATA OF COPPER(II) COMPLEXES

\begin{tabular}{|c|c|c|c|c|c|c|c|c|c|}
\hline \multirow{2}{*}{ Complex } & \multirow{2}{*}{ Colour } & \multirow{2}{*}{$\begin{array}{l}\text { Yield } \\
(\%)\end{array}$} & \multirow{2}{*}{ m.w. } & \multirow{2}{*}{$\begin{array}{l}\text { m.p. }{ }^{*} \\
\left({ }^{\circ} \mathrm{C}\right)\end{array}$} & \multicolumn{4}{|c|}{ Elemental analysis (\%): Found (Calcd.) } & \multirow{2}{*}{$\begin{array}{l}\text { Molar conductivity } \\
\qquad\left(\Omega \mathrm{cm}^{2} \mathrm{~mol}^{-1}\right)\end{array}$} \\
\hline & & & & & $\mathrm{C}$ & $\mathrm{H}$ & $\mathrm{N}$ & $\mathrm{M}$ & \\
\hline $\mathrm{Cu}(\mathrm{ATAH})_{2}$ & Light green & 72 & 423.6 & 290 & $45.10(45.32)$ & $4.28(4.25)$ & $13.60(13.22)$ & $14.70(15.00)$ & 4.9 \\
\hline $\mathrm{Cu}(\mathrm{ATBH})_{2}$ & Dark green & 70 & 547.5 & 280 & $57.25(56.98)$ & $4.40(4.38)$ & $10.15(10.22)$ & $11.50(11.60)$ & 4.1 \\
\hline
\end{tabular}

"Decomposition temperatures

separately containing solidified agar media. The prepared sterile filter paper discs were dipped into the compound solutions and shaken well and these test plates incubated for a period of 2 days in BOD at $37^{\circ} \mathrm{C}$ for the development of inhibitory zones. An average of two independent readings for each organism for different compound solutions was documented. The inhibition zones were measured after $24 \mathrm{~h}$ at $37^{\circ} \mathrm{C}$. The diameter of the inhibition zone was measured and recorded using plastic ruler.

\section{RESULTS AND DISCUSSION}

The complexes are sparingly soluble in $\mathrm{H}_{2} \mathrm{O}$ and less soluble in $\mathrm{CH}_{3} \mathrm{OH}$ and $\mathrm{C}_{2} \mathrm{H}_{5} \mathrm{OH}$, but readily soluble in $\mathrm{CH}_{3} \mathrm{CN},\left(\mathrm{CH}_{3}\right)_{2} \mathrm{SO}$ and $\left(\mathrm{CH}_{3}\right)_{2} \mathrm{NC}(\mathrm{O}) \mathrm{H}$. Molecular formulae of the $\mathrm{Cu}(\mathrm{II})$ complexes are proposed based on analytical data. The complexes are non-electrolytes (Table-1). The magnetic moment values of the complexes are relative to their respective spin-only values.

IR spectral data of acetylthiophene acetoylhydrazone (ATAH) and 2-acetylthiophene benzoylhydrazone (ATBH) and their copper(II) complexes and their assignments are given in Table-2. Data and assignments suggested that the heterocyclic sulphur atom, azomethine nitrogen atom and oxygen atom are involved in chelation.

\begin{tabular}{ccc} 
TABLE-2 \\
IMPORTANT IR SPECTRAL BANDS* \\
$\left(\mathrm{cm}^{-1}\right)$ AND THEIR ASSIGNMENT \\
\hline $\mathrm{Cu}(\mathrm{ATAH})_{2}$ & $\mathrm{Cu}(\mathrm{ATTH})_{2}$ & Assignment \\
\hline- & - & $v(\mathrm{~N}-\mathrm{H})$ \\
$(3174)$ & $(3327)$ & \\
- & - & $v(\mathrm{C}=\mathrm{O})$ \\
$(1666)$ & $(1651)$ & $v(\mathrm{C}=\mathrm{N})$ \\
1590 & 1502 & \\
$(1606)$ & $(1508)$ & $v(\mathrm{Cu}-\mathrm{O})$ \\
476 & 472 & $v(\mathrm{Cu}-\mathrm{N})$ \\
407 & 393 &
\end{tabular}

*Ligands' bands are given in parenthesis

In FTIR spectrum of acetylthiophene acetoylhydrazone (ATAH), the bands at $3174,1666,1606 \mathrm{~cm}^{-1}$ are assigned to $v(\mathrm{C}=\mathrm{N}), v(\mathrm{C}=\mathrm{O})$ and $v(\mathrm{NH})$ vibrations, respectively. The ${ }^{1} \mathrm{H}$ NMR spectra (recorded in $\mathrm{CDCl}_{3}$ solvent) shows $\delta(2.35)$ (singlet $3 \mathrm{H}), \delta(2.28)$ (singlet $3 \mathrm{H}), \delta(7.00-7.30)$ (multiplet $3 \mathrm{H}), \delta(9.50)$ (singlet $1 \mathrm{H}$ ) are respectively assigned to $-\mathrm{CH}_{3}$ (acetyl), $-\mathrm{CH}_{3}$ (acetoyl), thiophene and $>\mathrm{NH}$ protons. GC-MS spectrum of ATAH shows a peak at $m / z 182$ due to the formation of molecular ion.

The FTIR spectrum of 2-acetylthiophene benzoylhydrazone (ATBH) shows the peaks at 3327, 1651and $1608 \mathrm{~cm}^{-1}$, which are assigned to $v(\mathrm{C}=\mathrm{N}), v(\mathrm{C}=\mathrm{O})$ and $v(\mathrm{NH})$ vibrations, respectively. The ${ }^{1} \mathrm{H}$ NMR spectrum of ATBH (recorded in $\mathrm{CDCl}_{3}$ solvent) shows $\delta$ (2.34) (singlet $3 \mathrm{H}), \delta(7.03-8.00)$ multiplet $8 \mathrm{H}$ and $\delta(8.88)$ (singlet $1 \mathrm{H}$ ) respectively assigned to $-\mathrm{CH}_{3}$, and aromatic (thiophene + phenyl ring) protons and ${ }^{\circ} \mathrm{NH}$ protons. GC-MS spectrum of ATBH shows a peak at $m / z 244$ due to the formation of molecular ion.

UV-visible spectral data of complexes are given in Table-3. In the electronic spectra of $\mathrm{Cu}(\mathrm{ATAH})_{2}$ and $\mathrm{Cu}(\mathrm{ATBH})_{2}$, the bands at 27322 and $27030 \mathrm{~cm}^{-1}$ are related to $\mathrm{M}-\mathrm{L}$ charge transfer transitions. The spectra of $\mathrm{Cu}(\mathrm{ATAH})_{2}$ and $\mathrm{Cu}(\mathrm{ATBH})_{2}$ complexes showed symmetrical peaks at 12755 and 12936 $\mathrm{cm}^{-1}$, respectively. These weak Laporte forbidden bands are assigned to ${ }^{2} \mathrm{E}_{\mathrm{g}} \rightarrow{ }^{2} \mathrm{~T}_{2 \mathrm{~g}}$ electronic transition [1] in favour of octahedral geometry for the complexes.

\begin{tabular}{cccc}
\multicolumn{5}{c}{ TABLE-3 } \\
ELECTRONIC SPECTRAL DATA $\left(\mathrm{cm}^{-1}\right)$ OF \\
METAL COMPLEXES IN SOLUTION STATE*
\end{tabular}

Table-4 gives ESR spectral data of both $\mathrm{Cu}(\mathrm{II})$ complexes. Well resolved peaks are observed (Fig. 1) at low field and at high field region and these are related to $g_{\|}$and $g_{\perp}$, respectively. Tetracyanoethylene (TCNE) free radical was used as the $g$ marker for computing $g$ values.

The $\mathrm{g}_{\|}$values for $\mathrm{Cu}(\mathrm{ATAH})_{2}$ and $\mathrm{Cu}(\mathrm{ATBH})_{2}$ complexes are respectively found to be 2.415 and 2.253 . The $g_{\perp}$ values suggest ionic character for former complex and covalent character for latter complex [30]. The trend, $\mathrm{g}_{\|}>\mathrm{g}_{\perp}>2.0023$ suggested that the unpaired electron predominantly in the $d_{x^{2}-y^{2}}$ orbital [31,32] characteristic of octahedral geometry. The axial symmetry parameter $\mathrm{G}$ is defined as:

TABLE-4

HAMILTONIAN AND ORBITAL REDUCTION PARAMETERS OF COPPER(II) COMPLEXES

\begin{tabular}{|c|c|c|c|c|c|c|c|c|c|c|c|c|c|}
\hline \multirow{2}{*}{ Complex } & \multicolumn{4}{|c|}{ In DMF at RT } & \multicolumn{9}{|c|}{ In DMF at LNT } \\
\hline & $\mathrm{g}_{\|}$ & $\mathrm{g}_{\perp}$ & $\mathrm{g}_{\mathrm{av}}$ & $\mathrm{G}$ & $\mathrm{g}_{\|}$ & $\mathrm{g}_{\perp}$ & $\mathrm{g}_{\mathrm{av}}$ & $\mathrm{G}$ & $\lambda$ & $\mathrm{K}_{\|}$ & $\mathrm{K}_{\perp}$ & $\mathrm{A}_{\|} \times 10^{5}$ & $\mathrm{~A}_{\perp} \times 10^{5}$ \\
\hline $\mathrm{Cu}(\mathrm{ATAH})_{2}$ & 2.142 & 2.028 & 2.066 & 4.48 & 2.415 & 2.079 & 2.181 & 5.334 & 659 & 0.891 & 0.755 & 0.00238 & 0.00018 \\
\hline $\mathrm{Cu}(\mathrm{ATBH})_{2}$ & 2.149 & 2.006 & 2.054 & 3509 & 2.225 & 2.092 & 2.136 & 2.478 & 360 & 0.656 & 0.846 & - & - \\
\hline
\end{tabular}




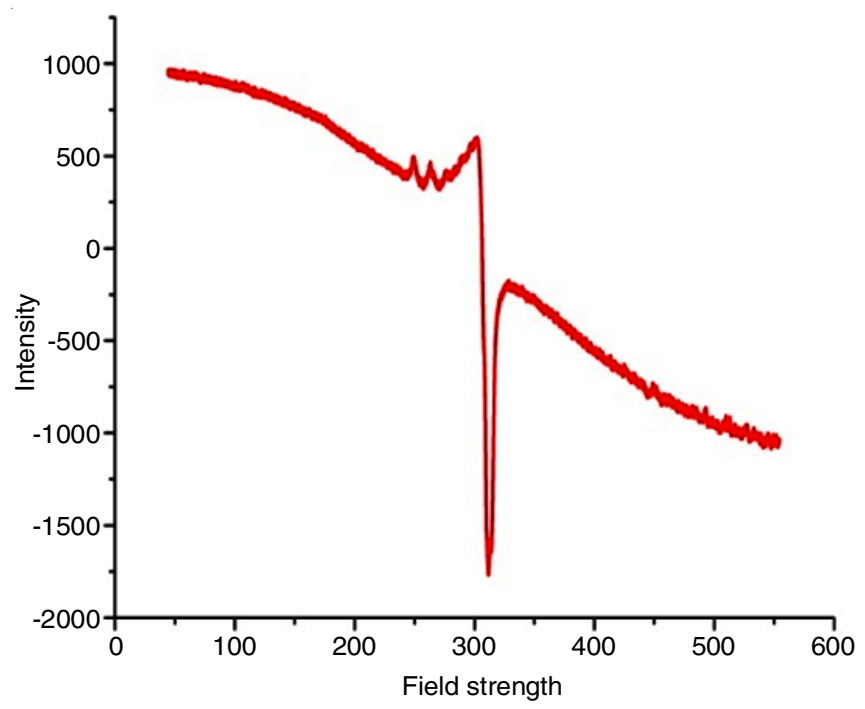

Fig. 1. ESR spectrum of $\mathrm{Cu}(\mathrm{ATAH})_{2}$ complex at LNT

$$
\mathrm{G}=\frac{\left[\mathrm{g}_{\|}-2.0023\right]}{\left[\mathrm{g}_{\perp}-2.0023\right]}
$$

The calculated $\mathrm{G}$ value for $\mathrm{Cu}(\mathrm{ATAH})_{2}$ and $\mathrm{Cu}(\mathrm{ATBH})_{2}$ complexes are respectively found to be 5.33 and 2.47 . The $\mathrm{G}$ value is more than 4 for $\mathrm{Cu}(\mathrm{ATAH})_{2}$ complex which indicates the absence of exchange coupling and mis-alignment of molecular axes. The $\mathrm{G}$ value is less than 4 for $\mathrm{Cu}(\mathrm{ATBH})_{2}$ complex which indicates the absence of exchange coupling and misalignment of molecular axes.

The following equations are used in the calculation of orbital reduction parameters $\left(\mathrm{K}_{\|}, \mathrm{K}_{\perp}\right)$ :

$$
\begin{gathered}
g_{\|}=g_{e}-\frac{8 K_{\|}{ }^{2} \lambda}{\Delta E(d-d)} \\
g_{\perp}=g_{e}-\frac{2 K_{\perp}{ }^{2} \lambda}{\Delta E(d-d)}
\end{gathered}
$$

Hathaway pointed that that for pure sigma bonding $\mathrm{K}_{\|}=$ $K_{\perp}=0.77$ and for in-plane pi bonding $K_{\|}<K_{\perp}$, while for outplane pi bonding $\mathrm{K}_{\|}>\mathrm{K}_{\perp}$.

For $\mathrm{Cu}(\mathrm{ATAH})_{2}$ complex, $\mathrm{K}_{\|}$and $\mathrm{K}_{\perp}$ are found to be 0.891 and 0.755 , respectively. These values suggested the presence of out-plane $\pi$-bonding in the complex. For $\mathrm{Cu}(\mathrm{ATBH})_{2}$ complex
$\mathrm{K}_{\|}$and $\mathrm{K}_{\perp}$ are 0.656 and 0.846 , respectively. These values suggested the presence of in-plane $\pi$-bonding in the complex.

The covalency factor $\left(\alpha^{2}\right)$ is evaluated by the following expression:

$$
\alpha^{2}=\mathrm{A}_{\|} / \mathrm{p}+\left(\mathrm{g}_{\|}-2.0023\right) 3 / 7\left(\mathrm{~g}_{\perp}-2.0023\right)+0.004
$$

The $\alpha^{2}$ value for the complex (0.3085) suggested the covalent nature of metal ligand bond.

The dipolar term $\mathrm{P}$ is estimated from the expression

$$
\left.\mathrm{P}=\left(\mathrm{A}_{\|}-\mathrm{A}_{\perp}\right) /\left(\mathrm{g}_{\|}-2\right)-5 / 4 \mathrm{~g}_{\perp}-2\right)-6 / 7
$$

Giordano and Bereman [33] suggested the identification of bond on groups from the values of dipolar term "P". The redu-ction of " $\mathrm{P}$ " value from the free ion value $\left(0.036 \mathrm{~cm}^{-1}\right)$ may be attributed to the presence of covalent character of $\mathrm{M}-\mathrm{L}$ bonding.

Antibacterial activity studies: The antibacterial activities of hydrazone ligands and their copper(II) complexes were investigated. The zone inhibition diameters $(\mathrm{mm})$ are given in Table-5. The compound 2-acetylpyridine acetoylhydrazone (APAH) shows more activity than 2-acetylpyridine benzoylhydrazone (APBH). Similarly, 2-acetylthiophene acetoylhydrazone (ATAH) is more active than 2-acetylthiophene benzoylhydrazone (ATBH). This trend indicates that acetoylhydrazones are more active than benzoylhydrazones against Gram-positive and Gramnegative bacteria. Moreover, APAH is more active than ATAH and APBH is more active than ATBH. This trend suggested that pyridine based hydrazones show more activity than thiophene based hydrazones against Gram-positive and Gramnegative bacteria.

The data given in Table-5 also suggested that the ligands showed more activity against E. coli and Staphylococcus aureus than the complexes. However, copper(II) complexes exhibited higher antibacterial activity than the free ligand, in the cases of Bacillus and P. aureoginosa in analogy with previous observations [34-36]. Overtone's concept [37] and Tweedy's chelation theory [38] would explain the enhanced activity of complexes. According to former concept, the lipid membrane surrounding the cell support the passage of only lipid-soluble materials,

\begin{tabular}{|c|c|c|c|c|c|c|c|c|c|c|c|c|}
\hline \multirow{5}{*}{ Compound } & \multicolumn{12}{|c|}{$\begin{array}{l}\text { TABLE-5 } \\
\text { 3ASED HYI }\end{array}$} \\
\hline & \multicolumn{12}{|c|}{ Zone of inhibition (mm) } \\
\hline & \multicolumn{6}{|c|}{ Gram-negative } & \multicolumn{6}{|c|}{ Gram-positive } \\
\hline & \multicolumn{3}{|c|}{ E. coli } & \multicolumn{3}{|c|}{ P. aureoginosa } & \multicolumn{3}{|c|}{ B. cereus } & \multicolumn{3}{|c|}{ S. aureus } \\
\hline & $200 \mu \mathrm{g}$ & $300 \mu \mathrm{g}$ & $500 \mu \mathrm{g}$ & $200 \mu \mathrm{g}$ & $300 \mu \mathrm{g}$ & $500 \mu \mathrm{g}$ & $200 \mu \mathrm{g}$ & $300 \mu \mathrm{g}$ & $500 \mu \mathrm{g}$ & $200 \mu \mathrm{g}$ & $300 \mu \mathrm{g}$ & $500 \mu \mathrm{g}$ \\
\hline APAH & 4.2 & 5.6 & 6.6 & 7.0 & 8.0 & 8.5 & 5.0 & 6.0 & 6.5 & 7.0 & 8.0 & 9.0 \\
\hline $\mathrm{Cu}(\mathrm{APAH})_{2}$ & 2.5 & 2.7 & 3.0 & 2.5 & 2.5 & 3.3 & 4.0 & 5.0 & 7.0 & 4.0 & 5.0 & 5.5 \\
\hline APBH & 2.0 & 4.0 & 6.0 & 6.0 & 7.0 & 7.5 & 5.0 & 5.5 & 6.0 & 4.0 & 6.0 & 8.0 \\
\hline $\mathrm{Cu}(\mathrm{APBH})_{2}$ & 1.5 & 1.7 & 2.4 & 4.5 & 6.6 & 8.4 & 6.0 & 6.5 & 7.0 & 2.5 & 4.0 & 6.0 \\
\hline ATAH & 4.0 & 6.0 & 6.5 & 5.0 & 6.0 & 7.0 & 5.0 & 6.0 & 7.0 & 6.0 & 8.0 & 9.0 \\
\hline $\mathrm{Cu}(\mathrm{ATAH})_{2}$ & 2.2 & 2.5 & 3.4 & 6.2 & 7.3 & 8.4 & 4.0 & 4.2 & 5.0 & 4.0 & 5.0 & 5.5 \\
\hline ATBH & 3.5 & 4.5 & 5.5 & 5.0 & 5.0 & 6.0 & 4.0 & 5.0 & 6.0 & 4.0 & 6.0 & 7.0 \\
\hline $\mathrm{Cu}(\mathrm{ATBH})_{2}$ & 2.4 & 2.8 & 3.6 & 8.3 & 8.5 & 9.2 & 5.0 & 5.5 & 6.0 & 3.0 & 5.0 & 7.0 \\
\hline
\end{tabular}
which means that lipid solubility is an important element for controlling antimicrobial activity. The polarity of a metal ion is greatly reduced on chelation. Delocalization of $\pi$-electrons over the whole chelating ring enhances the penetration ability

APAH = 2-Acetyl pyridine acetoylhydrazone; APBH = 2-Acetylpyridine benzoylhydrazone; ATAH = 2-Acetyl thiophene acetoylhydrazone; $\mathrm{ATBH}=2$-Acetyl thiophene benzoylhydrazone 
of the complexes into the lipid membranes. Metal ion is released when the complex enters the cell. The ligand free metal ion inhibits enzymes of the microorganisms [39].

\section{Conclusion}

In the present study two ligands viz. 2-acetylthiophene acetoylhydrazone (ATAH) and 2-acetylthiophene benzoylhydrazone (ATBH) were synthesized and characterized based on spectral data. Copper(II) complexes of these functionalized hydrazones were investigated. Current studies revealed that the complexes have general formula $\mathrm{ML}_{2}$ (where, $\mathrm{L}=\mathrm{ATAH}$ and ATBH) and acted as monoanioninc tridentate ligands. Copper complexes are six coordinated and have octahedral structure. Copper(II) complexes showed more activity than the corresponding hydrazone ligands.

\section{ACKNOWLEDGEMENTS}

One of the authors, KHR is thankful to UGC, New Delhi for the sanction of one-time grant (sanction Lr. No. F. 19-106/ 2013 (BSR) as financial support. The authors are also thankful to the authorities of SAIF Centers of IIT-Madras and IITBombay, India for providing the spectral analysis. The authors thank UGC and DST, New Delhi, for providing the equipment facilities under UGC-SAP and DST-FIST programs, respectively.

\section{CONFLICT OF INTEREST}

The authors declare that there is no conflict of interests regarding the publication of this article.

\section{REFERENCES}

1. K.H. Reddy, Bioinorganic Chemistry, New Age International Publishers: New Delhi, p. 176 (2003).

2. G. Grass, C. Rensing and M. Solioz, Appl. Environ. Microbiol., 77, 1541 (2011);

https://doi.org/10.1128/AEM.02766-10.

3. I.P. Ejidike and P.A. Ajibade, Rev. Inorg. Chem., 35, 191 (2015); https://doi.org/10.1515/revic-2015-0007.

4. S. Rollas and S. Kücükgüzel, Molecules, 12, 1910 (2007); https://doi.org/10.3390/12081910.

5. L.N. Suvarapu, Y.K. Seo, S.-O. Baek and V.R. Ammireddy, E-J. Chem., 9, 1288 (2012); https://doi.org/10.1155/2012/534617.

6. H.A. Ghazy Mostafa, S.A. El-farra and A.S. Fouda, Indian J. Chem. Technol., 11, 787 (2004).

7. M.R. Maurya, C. Haldar, A. Kumar, M.L. Kuznetsov, F. Avecilla and J. Costa Pessoa, Dalton Trans., 42, 11941 (2013); https://doi.org/10.1039/c3dt50469g.

8. J. Yadav, J.S.N. Pandeya and S.P. Singh, J. Chem. Pharm. Res., 2, 558 (2010).

9. L.S. Lerman, J. Mol. Biol., 3, 18 (1961); https://doi.org/10.1016/S0022-2836(61)80004-1.

10. R.L. Dutta and M.M. Hossain, J. Sci. Ind. Res., 33, 635 (1985).

11. Y. Shechter, I. Goldwash, M. Micronchik, M. Fridkin and D. Gefel, Coord. Chem. Rev., 237, 3 (2003); https://doi.org/10.1016/S0010-8545(02)00302-8.

12. D. Rehder, Inorg. Chem. Commun., 6, 604 (2003); https://doi.org/10.1016/S1387-7003(03)00050-9.
13. K.H. Thompson and C. Orvig, Coord. Chem. Rev., 219-221, 1033 (2001); https://doi.org/10.1016/S0010-8545(01)00395-2.

14. G. Verquin, G. Fontaine, M. Bria, E. Zhilinskaya, E. Abi-Aad, A. Aboukaïs, B. Baldeyrou, C. Bailly and J.-L. Bernier, J. Biol. Inorg. Chem., 9, 345 (2004); https://doi.org/10.1007/s00775-004-0529-0.

15. N. Raman, A. Kulandaisamy and K. Jeyasubramanian, Synth. React. Inorg. Met.-Org. Chem., 34, 17 (2004); https://doi.org/10.1081/SIM-120027315.

16. M.M.E. Shakdofa, M.H. Shtaiwi, N. Morsy and T.M.A. Abdel-rassel, Main Group Chem., 13, 187 (2014); https://doi.org/10.3233/MGC-140133.

17. A.A. Recio Despaigne, J.G. Da Silva, A.C.M. Do Carmo, O.E. Piro, E.E. Castellano and H. Beraldo, J. Mol. Struct., 920, 97 (2009); https://doi.org/10.1016/j.molstruc.2008.10.025.

18. Y.J. Jang, U.K. Lee and B.K. Koo, Bull. Korean Chem. Soc., 26, 925 (2005); https://doi.org/10.5012/bkcs.2005.26.6.925.

19. K. Raja, A. Suseelamma and K.H. Reddy, J. Chem. Sci., 128, 1265 (2016); https://doi.org/10.1007/s12039-016-1125-x.

20. K. Raja, A. Suseelamma and K.H. Reddy, J. Chem. Sci., 128, 23 (2016); https://doi.org/10.1007/s12039-015-1003-y.

21. K. Raja, A. Suseelamma and K.H. Reddy, J. Iran. Chem. Soc., 12, 1473 (2015); https://doi.org/10.1007/s13738-015-0624-x.

22. K.H. Reddy, K. Raja and A. Suseelamma, Inorg. Nano-Metal Chem., 47, 1398 (2017); https://doi.org/10.1080/24701556.2017.1284129.

23. M. Pragathi and K.H. Reddy, Asian J. Chem., 31, 148 (2019); https://doi.org/10.14233/ajchem.2019.21558.

24. P. Hari Babu and K.H. Reddy, Indian J. Chem., 52A, 327 (2013).

25. M. Pragahi and K.H. Reddy, Indian J. Chem., 52A, 845 (2013).

26. M. Pragathi and K.H. Reddy, Inorg. Chim. Acta, 413, 174 (2014); https://doi.org/10.1016/j.ica.2014.01.010.

27. P. Haribabu, Y.P. Patil, K.H. Reddy and M. Nethaji, Transition Met. Chem., 39, 167 (2014); https://doi.org/10.1007/s11243-013-9786-5.

28. H. Pagonda, P.P. Yogesh, H.R. Katreddi and N. Munirathinam, Inorg. Chim. Acta, 392, 478 (2012); https://doi.org/10.1016/i.ica.2012.03.042.

29. A.B.P. Lever, Inorganic Electronic Spectroscopy, Elsevier: Amsterdam, edn 2 (1984).

30. D. Kivelson and R. Neiman, J. Chem. Phys., 35, 149 (1961); https://doi.org/10.1063/1.1731880.

31. N. Raman, A. Kulandaisamy and K. Jayesubramanian, Indian J. Chem., 41A, 942 (2002).

32. S.M. Mamdoush, S.M. Abou Elenein and H.M. Kamel, Indian J. Chem., 41A, 297 (2002).

33. R.S. Giordano and R.D. Bereman, J. Am. Chem Soc., 96, 1019 (1974); https://doi.org/10.1021/ja00811a012.

34. R.V. Prasad and N.V. Thakkar, J. Mol. Catal., 92, 9 (1994); https://doi.org/10.1016/0304-5102(94)00063-8.

35. S. Belaid, A. Landreau, S. Djebbar, O. Benali-Baitich, G. Bouet and J.-P. Bouchara, J. Inorg. Biochem., 102, 63 (2008); https://doi.org/10.1016/j.jinorgbio.2007.07.001.

36. N. Dharmaraj, P. Viswanathamurthi and K. Natarajan, Transition Met. Chem., 26, 105 (2001); https://doi.org/10.1023/A:1007132408648.

37. B.G. Tweedy, Phytopathology, 55, 910 (1964).

38. M.A. Neelakantan, M. Esakkiammal, S.S. Mariappan, J. Dharmaraja and T. Jeyakumar, Indian J. Pharm. Sci., 72, 216 (2010); https://doi.org/10.4103/0250-474X.65015.

39. Z.H. Chohan, A.K. Misbahul and M. Moazzam, Indian J. Chem., 27A, 1102 (1988). 